\title{
FACTOR ANALYSIS OF THE CHALLENGES AND STRATEGIES FOR EFFECTIVE WORK-BASED LEARNING IN NIGERIAN TECHNICAL AND VOCATIONAL EDUCATION
}

\author{
Rabiu Haruna ${ }^{1}$ and Yusri Bin Kamin ${ }^{2}$ \\ ${ }^{12}$ Department of Technical and Engineering Education, School of Education, Universiti Teknologi Malaysia, Johor \\ Bahru, Malaysia \\ ${ }^{1}$ Department of Electrical and Electronic Technology, SOSE (Technical), Federal College of Education (Technical) \\ Bichi, Kano, Nigeria \\ Email: p-yusri@utm.my
}

\begin{abstract}
This study investigated challenges and strategies for effective work-based learning in Nigerian technical and vocational education (TVE) using a factor analysis approach. Through the use of structured questionnaire, the opinions of 385 respondents consisting of 227 TVE lecturers and 158 supervisors of technical and vocational firms were sought. The data collected were analyzed using descriptive statistics and varimax rotated principal component factor analysis with factor loading of 0.40 . The result showed that about $25 \%$ of the TVE firms in Northwest Nigeria are industrial technical firms, $22 \%$ are computer/ICT, $19 \%$ are business/distributive trade, $18 \%$ are home economics while about $16 \%$ are agricultural based. Using principal component factor analysis, the study identified: policy, funding, attitudinal and linkage as challenging factors undermining effectiveness of work-based learning in Nigerian TVE. On the other hand, training, administrative, institutional and facility/curriculum are strategic factors for effectiveness of work-based learning in Nigerian TVE. Based on the findings, the study among others recommended strong technical and vocational education linkage with industry for skills training of students through work-based learning framework and approach.
\end{abstract}

Keywords: challenges, strategies, technical and vocational education, work-based learning

\section{INTRODUCTION}

Education, especially the type that leads to technical and vocational skills acquisition, industrial and technological development has been a panacea for national development, self-reliance and citizenship empowerment. UNESCO described TVE as all forms of education that involves, in addition to general education, the study of technologies and related sciences and the acquisition of practical skills, attitudes, understanding and knowledge relating to occupation in various sectors of economic life [1]. Awo [2] affirmed that TVE forms an integral part of general education for preparing people for occupational fields for effective participation in the world of work in order to promote sustainable development through employment generation and poverty alleviation. This is because, TVE provides its recipients with the basic cognitive and practical skills necessary for entrance into the labour market as employees or as selfemployed.

Considering the relevance of TVE, Unongo [3] noted that TVE is receiving global attention because of its strategic position as a veritable tool for national development and a solution for curbing unemployment amongst youths. Manyindo [4] emphasized that TVE is expected to provide youths with knowledge, skills and training that satisfy the human resource demand of the nation. The components of TVE are imbedded into the Nigerian educational system from the basic, post basic and tertiary education levels. 
According to Nwosu \& Micah [5], the essence of incorporating TVE into all level of Nigerian education is to place emphasis on skills development and entrepreneurship development of the citizens. Federal Republic of Nigeria revealed that the curriculums of TVE in Nigeria are carefully prepared to be practical oriented to ensure the achievement of their set goals and objectives which include: (i) provision of trained man-power in applied sciences, technology and business, (ii) provision of technical knowledge and vocational skill necessary for economic development and (iii) giving training and imparting necessary skill for economic self-reliance [6].

Dike hinted that TVE has been a key component of national development plans in industrialized nations as a result of its impact on productivity, economic and industrial advancement [7]. For instance, the United States, Singapore, Germany, China, India, Japan, Korea and Indonesia school systems among others pay more attention to technical and vocational education centers that offer vocational training for lifelong trade together with general academic studies. The systems allow effective training in public technical and vocational schools and concurrently in a privately-owned registered businesses or entrepreneurship agencies for production of skilled man power required for economic and industrial revolution.

The $2^{\text {nd }}$ International Conference on Vocational and Technical Education held in Korea 1999 set the mission for all nations to use VTE to address the employment and or other socio-economic challenges of the 21 st century. Unarguably, the Nigerian technical and vocational education faced some notable challenges undermining the achievement of objectives of a functional technical and vocational education and training. Okoye affirmed that technical and vocational education in Nigeria cannot contribute greatly to the reduction of abject poverty, hunger and unemployment because it is handicapped by numerous challenges [8]. Oranu observed that the good intentions of successive Nigerian governments about TVE programmes are hurt with a lot of challenges [9]. Okoye [8] noted further that available facilities and programmes of instruction of Nigerian technical and vocational education are inadequate quantitatively and qualitatively. OryemOriga reported that that less $40 \%$ of institutions of higher learning in Nigeria has laboratory or workshop space for technical education programmes while the remaining $60 \%$ do not have laboratory or workshop space and this has resulted to the low quality of technical and vocational education in Nigeria [10]. The present teaching and learning of TVE in Nigeria is basically theoretical through classroom instruction with little or no adequate attempt to complement classroom instruction with work-based learning for acquisition of needed practical technical and vocational skills for work.

Work-based learning (WBL) is an instructional arrangement in which learners are concurrently exposed to instruction in both work and learning environments. Okon described WBL as an experiential learning programme that use the work environment as an important component of the curriculum to complement classroom teaching. Through WBL, structured learning experiences are provided to the learners through the collaborative efforts of employers of labour and the school [11]. Amadi stated that WBL arrangement avails learners opportunities to acquire a variety of skills upon exposure to rigorous academic engagements simultaneously with hands-on 
career development experiences [12]. According to Jerrard and Jefsionutine, WBL forges a formidable link between classroom instruction and the world of work to guarantee the occurrence of appropriate learning to the extent of satisfying the requirements of the world of work [13].

Kamin et al. [14] observed that, as a workplace learning environment, the application of the WBL programme genuinely involves real experiences when it transforms theory into practice in the workplace context. Schrenko [15] recommended that a work-based learning programme must include work experience opportunities, job training and work experiences coordinated with both academic and occupational learning in school-based programmes that are relevant to students' programme of study.

Amadi [12] submitted that career development is a component of WBL that exposes learners to varieties of work settings to assists them in making decisions about future career direction and occupations as practice in industrialized countries. Awo [2] stated that technical and vocational education has been a fundamental feature in development strategies of many developed countries because of its impact on productivity and economic development. Despite the overwhelming recognition of its roles in technological advancement and nation economic development, technical and vocational education in Nigeria is not well linked to the industry for acquisition of needed skills and competencies for work. Hence, this study empirically investigated challenges and strategies for effective workbased learning in Nigerian Technical and Vocational Education using factor analysis approach.

\section{METHOD}

The study was carried out in Northwest, Nigeria using a survey research design. Northwest Nigeria is made up of seven states which includes Jigawa, Kaduna, Kano, Katsina, Kebbi, Sokoto and Zamfara.

Simple random sampling technique through balloting was used to select two states (Kaduna and Kano) out the existing seven states in the northwest Nigeria. From the two selected states, the five public universities and four colleges of education that offers TVE were sampled. The entire 227 lecturers of TVE in the sampled nine tertiary institutions were involved as respondents in the research. In addition to the 227 TVE lecturers, the entire 158 supervisors of registered technical and vocational firms in the two states were also selected making a total of 385 respondents for the research.

Data for this study were obtained using structured close-ended questionnaire titled Challenges and Strategies for Effective Work-based Learning Questionnaire (CSEWBLQ). The instrument was facevalidated by five experts in technical and vocational education in northwest Nigeria.

Data collected were analyzed using descriptive statistics such as frequency, percentages and charts to present different forms of technical and vocational firms in the area. Varimax rotated principal component factor analysis was used to analyse challenges and strategies for effective workbased learning in Nigerian Technical and Vocational Education.

Principal component factor analysis was employed to identify challenges and strategies for effective work-based learning. To group the identified challenges and strategies, the principal component analysis 
with varimax rotation was adopted with factor loading of 0.30 . Therefore, factor loading of less than 0.30 or variables that loaded in more than one factor were discarded. The principal component factor analysis model was given as:

$\mathrm{Y}_{1}=\mathrm{a}_{11} \mathrm{X}_{1}+\mathrm{a}_{12} \mathrm{X}_{2}+* * *+\mathrm{a}_{1 \mathrm{n}} \mathrm{X}_{\mathrm{n}}$

$\mathrm{Y}_{2}=\mathrm{a}_{21} \mathrm{X}_{1}+\mathrm{a}_{22} \mathrm{X}_{2}+* * *+\mathrm{a}_{2 \mathrm{n}} \mathrm{X}_{\mathrm{n}}$

$\mathrm{Y}_{3}=\mathrm{a}_{31} \mathrm{X}_{1}+\mathrm{a}_{32} \mathrm{X}_{2}+* * *+\mathrm{a}_{3 \mathrm{n}} \mathrm{X}_{\mathrm{n}}$

$*=$

$\mathrm{Y}_{\mathrm{n}}=\mathrm{a}_{\mathrm{n} 1} \mathrm{X}_{1}+\mathrm{a}_{\mathrm{n} 2} \mathrm{X}_{2}+* *+\mathrm{a}_{\mathrm{nn}} \mathrm{X}_{\mathrm{n}}$

Where:

$\mathrm{Y}_{1}, \mathrm{Y}_{2} \ldots \mathrm{Y}_{\mathrm{n}}=$ observed variables (challenges or strategies) for effective work-based learning in TVE

$a_{1}-a_{n}=$ factor loadings or correlation coefficients.

$\mathrm{X}_{1}, \mathrm{X}_{2}, \ldots \mathrm{X}_{\mathrm{n}}=$ unobserved underlying factors (challenges or strategies) for effective workbased learning in TVE.

\section{RESULTS AND DISCUSSION}

The bar chart in Figure 1 showed that about $25 \%$ of the TVE firms in Northwest Nigeria where students engage in workbased learning are industrial technical firms such as wood work, metal work, building, electrical/electronic and mechanical. About $22 \%$ of the firms are computer/ICT oriented firms, $19 \%$ are business/distributive trade firms, about $18 \%$ are Home Economics related (clothing and textile, food and nutrition and home management) while about $16 \%$ of the TVE firms are agricultural based such as crop production, livestock production and agricultural processing where students observe work-based learning. Amadi \& Lazarus [16] reported that the enrolment of students in vocational agriculture is very low relative to other aspects of technical and vocational education.
Table 1 presented the varimax-rotated principal component factor analysis of challenging factors undermining effectiveness of work-based learning in Nigerian technical and vocational education. From the result presented in the Table 1, four factors were extracted. According to Ashley et al., only variables with factor loadings of 0.30 and above at $10 \%$ overlapping variance were used in naming the factors. Variables that loaded in more than one factors as in the case of variable 4 was discarded and not used while variable 3 that has factor loadings of less than 0.30 was not used [17]. Kessler [18] and Amusa et al. [19] stated that naming of each factor is based on the set of loaded variables the factor is composed of. This was equally adopted in this study to group the variables into four major factors which are: policy, funding, attitudinal and linkage fact.

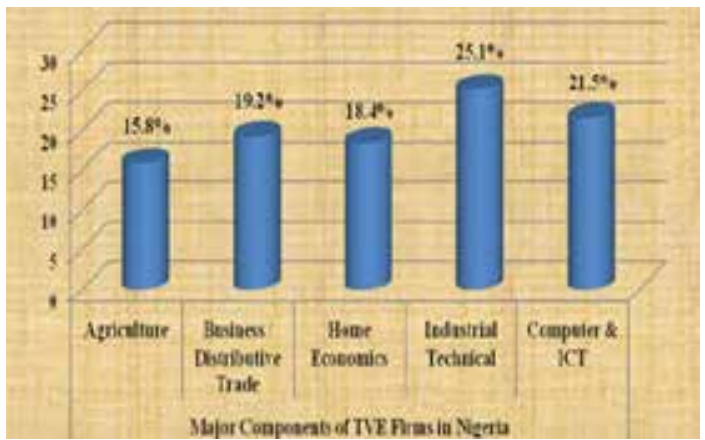

Figure 1. Bar Chart of Percentage Distributions of the Components of TVE Firms

Under the policy factor, the specific challenging variables undermining workbased learning in Nigerian TVE with their corresponding factor loadings include: non regulation of students' posting to industries (.476), ineffective policy framework for work-based learning (.621), deficient technical and vocational training (.590), lack of strategic plan to avoid frequent interruption in school academic calendar 
(.305) and lack of in-services training policy and program for TVE teachers and instructors (.348). Ikenga et al. identified militating factors against the development of vocational education to include poor government policy, lack of equipment and workshop, lack of qualified vocational teachers, inadequate funding and poor societal attitude towards vocational education [20].

Table 1. Principal Components Factor Analysis of Challenges of Work-based Learning in Nigerian Technical and Vocational Education

\begin{tabular}{|c|c|c|c|c|c|c|}
\hline \multirow[b]{2}{*}{ SN } & \multirow[b]{2}{*}{ Challenging variables } & \multicolumn{5}{|c|}{ Four Factor Components } \\
\hline & & $\begin{array}{l}\text { Policy } \\
\text { Factor }\end{array}$ & $\begin{array}{l}\text { Funding } \\
\text { Factor }\end{array}$ & $\begin{array}{l}\text { Attitudinal } \\
\text { Factor }\end{array}$ & $\begin{array}{l}\text { Linkage } \\
\text { Factor }\end{array}$ & $\begin{array}{l}\text { Eigen } \\
\text { Value }\end{array}$ \\
\hline 1 & $\begin{array}{l}\text { Rejection of students from training } \\
\text { institutions by managers of industries. }\end{array}$ & .084 & -.277 & .165 & .658 & 2.853 \\
\hline 2 & $\begin{array}{l}\text { Non regulation of students' posting to } \\
\text { industries of relevance to their training. }\end{array}$ & .476 & -.189 & -.164 & .297 & 2.279 \\
\hline 3 & $\begin{array}{l}\text { Lack of access to modern machines in the } \\
\text { industries by students trainees. }\end{array}$ & .270 & -.135 & -.180 & -.232 & 1.611 \\
\hline 4 & $\begin{array}{l}\text { Inadequate practical testing of students by } \\
\text { industrial based supervisors. }\end{array}$ & .253 & $.388 *$ & $-.331 *$ & -.038 & 1.359 \\
\hline 5 & $\begin{array}{l}\text { Ineffective supervision of TVE students } \\
\text { by school-based supervisors during WBL. }\end{array}$ & .257 & .236 & -.518 & -.054 & 1.188 \\
\hline 6 & $\begin{array}{l}\text { Ineffective policy framework for work- } \\
\text { based training period for TVE students. }\end{array}$ & .621 & -.161 & .197 & .223 & 1.100 \\
\hline 7 & $\begin{array}{l}\text { Inadequate provision of modern facilities } \\
\& \text { machines for teaching TVE }\end{array}$ & .066 & .436 & .100 & -.299 & 1.009 \\
\hline 8 & $\begin{array}{l}\text { Poor perception of Nigerian society about } \\
\text { technical \& vocational education. }\end{array}$ & .279 & .138 & .584 & .023 & .960 \\
\hline 9 & $\begin{array}{l}\text { Non-payment of stipends to students on } \\
\text { industrial training (IT) for makeup. }\end{array}$ & .244 & .504 & .085 & -.064 & .863 \\
\hline 10 & $\begin{array}{l}\text { Deficient technical and vocational } \\
\text { training offered in Nigerian schools. }\end{array}$ & .590 & -.227 & .130 & .055 & .779 \\
\hline 11 & $\begin{array}{l}\text { Poor institutions-industry linkage for } \\
\text { effective work-based learning. }\end{array}$ & .084 & .214 & -.225 & .626 & .724 \\
\hline 12 & $\begin{array}{l}\text { Poor attitude of students to enrolling in } \\
\text { technical and vocational education. }\end{array}$ & .208 & .188 & .465 & -.285 & .613 \\
\hline 13 & $\begin{array}{l}\text { Lack of strategic plan to avoid frequent } \\
\text { interruption in Nigeria school calendar }\end{array}$ & .305 & .214 & .113 & -.196 & .534 \\
\hline 14 & $\begin{array}{l}\text { Students' lack of dedication and interest } \\
\text { in TVE work-based learning. }\end{array}$ & .169 & -.170 & .659 & -.212 & .527 \\
\hline 15 & $\begin{array}{l}\text { Cases of sexual harassment of female } \\
\text { trainees by industrial supervisors. }\end{array}$ & .247 & -.019 & .351 & -.148 & .483 \\
\hline 16 & $\begin{array}{l}\text { Weak coordination of relevant agencies } \\
\text { on functional WBL program in Nigeria. }\end{array}$ & .136 & .270 & .152 & .393 & .459 \\
\hline 17 & $\begin{array}{l}\text { Lack of motivational incentives for } \\
\text { students on work-based learning. }\end{array}$ & .010 & .477 & -.047 & .214 & .437 \\
\hline 18 & $\begin{array}{l}\text { Lack of in-services training policy and } \\
\text { program for TVE teachers \& instructors }\end{array}$ & .348 & -.203 & .239 & .202 & .320 \\
\hline
\end{tabular}

Note: Factor loading of $\mathbf{0 . 3 0}$ was used at $10 \%$ overlapping variance.

Variables with factor loadings of less than $\mathbf{0 . 3 0}$ were not used.

**Variable 4 was discarded for loading in more than one factor.

The specific variables under attitudinal factor with their corresponding factor loadings include: ineffective supervision of TVE students by school-based supervisors (-.518), poor perception of Nigerian society about TVE (.584), poor attitude of students to enrolling in TVE (.465), students' lack of dedication and interest to work-based learning (.659) and cases of sexual harassment of female trainees by industrial 
supervisors (.351). Amadi noted that the enrolment of students in vocational agriculture is very low relative to other aspects of technical and vocational education. Ikenga et al. [20] cited poor societal attitude towards vocational education as part of the challenges of workbased learning approach of TVE.

Abassah [21] reported that general attitudes of the public towards technical education and training have been found to be negative. Under linkage factor, the variables undermining work-based learning in Nigerian Technical and Vocational Education include: rejection of students from training institutions by managers of industries (.658), poor institutions-industry linkage for effective work-based learning (.626) and weak coordination of relevant agencies on functional WBL program in Nigeria (.393). Alam [22] et al. noted that the poor linkage between vocational institutions and industries has resulted in poor learning of technical and vocational trades. Amu \& Ansah reported that the link between vocational and technical education systems and industry was weak resulting in serious mismatches between supply and demand for skills [23]. Figure 2 presents the scree plot on the appropriateness of number of factor components on Challenges of Work-based Learning

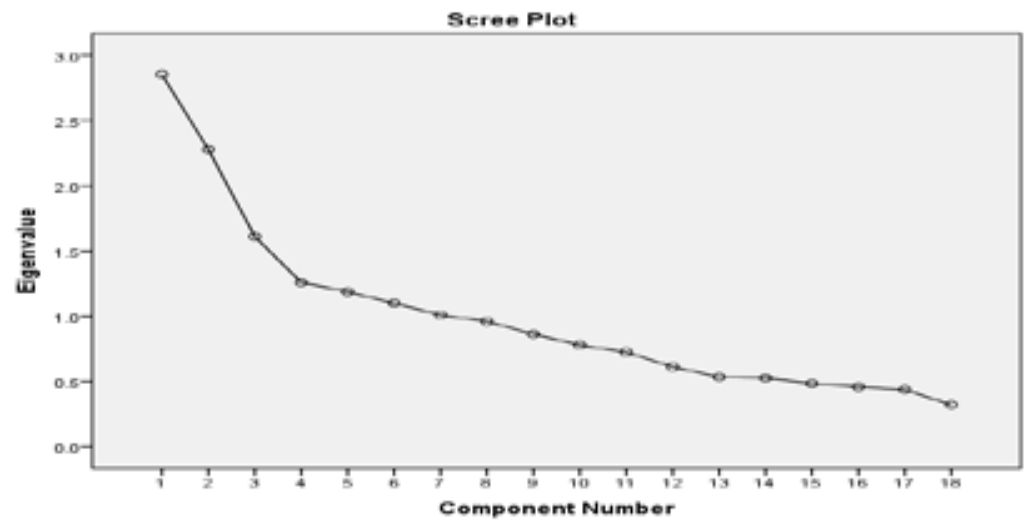

Figure 2. Scree Plot on the Appropriateness of Number of Factor Components on Challenges of Work-based Learning

Table 2 presents the varimax-rotated principal component factor analysis of strategies for effective work-based learning in Nigerian technical and vocational education. The result showed that four factors were extracted. Factor loading of 0.30 and above at $10 \%$ overlapping variance was used for naming the factors. Variables loaded in more than one factors as in the case of variables 4, 6 and 17 were discarded and not used while variable 10 that has factor loadings of less than 0.30 was not used. Hence, the four strategic factors include: training, administrative, institutional and facility/curriculum factors.

The specific strategic variables under training factor for promoting effective workbased learning in Nigerian TVE with their corresponding factor loadings include: mandatory continuous professional training of school and industrial supervisors (.593), capacity building and training of TVE instructors and lecturers (.554), creating more technical and vocational training centres for work-based learning (.367) and increased work-based learning period for TVE students for effective practical training (.366). 
Table 2. Principal Components Factor Analysis of Strategies for Effective Work-based Learning in Nigerian Technical and Vocational Education

\begin{tabular}{|c|c|c|c|c|c|c|}
\hline \multirow[b]{2}{*}{ SN } & \multirow[b]{2}{*}{ Strategy variables } & \multicolumn{5}{|c|}{ Four Factor Components } \\
\hline & & $\begin{array}{l}\text { Training } \\
\text { Factor }\end{array}$ & $\begin{array}{l}\text { Admin } \\
\text { Factor }\end{array}$ & $\begin{array}{l}\text { Institution } \\
\text { Factor }\end{array}$ & $\begin{array}{c}\text { Facility/ } \\
\text { Curriculum } \\
\text { Factor } \\
\end{array}$ & $\begin{array}{l}\text { Eigen } \\
\text { Value }\end{array}$ \\
\hline 1 & $\begin{array}{l}\text { Mandatory continuous professional training to } \\
\text { both school and industrial supervisors }\end{array}$ & .593 & -.163 & .129 & .063 & 4.832 \\
\hline 2 & $\begin{array}{l}\text { Increase use of modern machines and facilities } \\
\text { to stimulate students' interest in WBL. }\end{array}$ & .271 & .145 & .076 & .454 & 2.130 \\
\hline 3 & $\begin{array}{l}\text { Formulating comprehensive national TVE } \\
\text { work-based learning policy. }\end{array}$ & .282 & .352 & .025 & .229 & 1.866 \\
\hline 4 & $\begin{array}{l}\text { Generating a data pool of list of industries of } \\
\text { relevance for students training }\end{array}$ & $.588 *$ & .030 & $.394 *$ & .097 & 1.461 \\
\hline 5 & $\begin{array}{l}\text { Capacity building and training of TVE } \\
\text { instructors and lecturers. }\end{array}$ & .554 & .214 & .187 & .277 & 1.206 \\
\hline 6 & $\begin{array}{l}\text { Formulate 'no rejection' policy of students on } \\
\text { training to guide operators of industries }\end{array}$ & $.438^{*}$ & $.412 *$ & .058 & .131 & 1.191 \\
\hline 7 & $\begin{array}{l}\text { Increased government technical support in } \\
\text { technical and vocational education }\end{array}$ & .282 & -.705 & .079 & -.031 & 1.018 \\
\hline 8 & $\begin{array}{l}\text { Increased work-based learning research in } \\
\text { Nigerian high institutions }\end{array}$ & .213 & -.145 & .513 & -.097 & .869 \\
\hline 9 & $\begin{array}{l}\text { Retool TVE model to reflect the contents of } \\
\text { modern day world of work. }\end{array}$ & .163 & -.043 & .294 & -.460 & .715 \\
\hline 10 & $\begin{array}{l}\text { Increased awareness of work-based learning } \\
\text { for effective TVE in Nigeria }\end{array}$ & .084 & -.266 & -.188 & .233 & .633 \\
\hline 11 & $\begin{array}{l}\text { Creating more technical and vocational } \\
\text { training centres for work-based learning }\end{array}$ & .367 & .099 & .255 & .181 & .605 \\
\hline 12 & $\begin{array}{l}\text { Establish regulatory institution to strictly } \\
\text { control students posting to relevant industries. }\end{array}$ & .179 & -.218 & .457 & -.246 & .523 \\
\hline 13 & $\begin{array}{l}\text { Government payment of monthly allowance } \\
\text { throughout the training period }\end{array}$ & .270 & -.593 & .047 & .288 & .409 \\
\hline 14 & $\begin{array}{l}\text { Increased budget of TVE by government for } \\
\text { effective work-based learning }\end{array}$ & .047 & -.165 & .557 & .264 & .334 \\
\hline 15 & $\begin{array}{l}\text { Advocacy for government and institutional } \\
\text { funding of work-based learning in Nigeria. }\end{array}$ & .235 & .423 & -.055 & .159 & .282 \\
\hline 16 & $\begin{array}{l}\text { Introduction of a central industrial training } \\
\text { exam in the curriculum for students. }\end{array}$ & .278 & -.123 & .286 & .511 & .267 \\
\hline 17 & $\begin{array}{l}\text { Structure students research projects on solving } \\
\text { an indentified industrial problem. }\end{array}$ & .210 & $.396^{*}$ & $.560 *$ & -.205 & .189 \\
\hline 18 & $\begin{array}{l}\text { Allowing students on training have access to } \\
\text { needed information, facilities \& machines }\end{array}$ & .140 & .062 & .252 & .452 & .139 \\
\hline 19 & $\begin{array}{l}\text { Increased work-based learning period for TVE } \\
\text { students for effective practical training }\end{array}$ & .366 & -.246 & .213 & -.258 & .132 \\
\hline
\end{tabular}

Note: Factor loading of $\mathbf{0 . 3 0}$ was used at $10 \%$ overlapping variance. Variables with factor loadings of less than $\mathbf{0 . 3 0}$ were not used.

**Variables 4, 6 and 17 were discarded for loading in more than one factor.

Okoye et al. identified local and foreign training of TVE lecturers and instructors as a continuous exercise to ensure consistent improvement in the quality of their products [24]. Under administrative factor, the specific strategic variables for effective work-based learning and their corresponding factor loadings include: formulating comprehensive national TVE work-based learning policy (.352), increased government technical support in technical and vocational education (-.705), government payment of monthly allowance throughout the training period (-.593) and advocacy for government and institutional funding of work-based learning in Nigeria (.423). Amadi et al submitted that Nigerian Government should employ more personnel 
where needed, good infrastructural facilities to create good learning environment, and sound administrative strategies for continuous re-orientation of TVE programmes from time to time [16].

Under institutional factor, the specific variables for promoting effective workbased learning with their corresponding factor loadings include: increased workbased learning research in Nigerian high institutions (.513), establish regulatory institution to strictly control students posting to relevant industries (.457) and increased budget of TVE by government for effective work-based learning (.557). Ojimba reported that resources should be allocated to the relevant institutions and programmes in order to achieve positive outcomes [24].

A comprehensive reform of technical and vocational institutions is the only panacea to technological advancement of the country. The specific variables under facility/curriculum factor include: increase the use of modern machines and facilities to stimulate students' interest (.454), retooling TVE model to reflect the contents of modern-day world of work (-.460), introduction of a central industrial training exam in the curriculum for students (.511) and allowing students on training have access to needed information, facilities and machines (.452).

Okoye et al. [8] found that adequate resources should be allocated to technical and vocational education, well equipped laboratories, workshops, relevant textbooks, training manuals and update curriculum. Awo [2] reported that a balanced approach should be emphasized in TVE school curriculum through the integration of technical, employability, generalized, creative and innovative skills in technical and vocational programmes. Nwosu et al. in a study identified the fact that effective implementation of programmes and curriculum is important in Nigerian technical and vocational education [5].

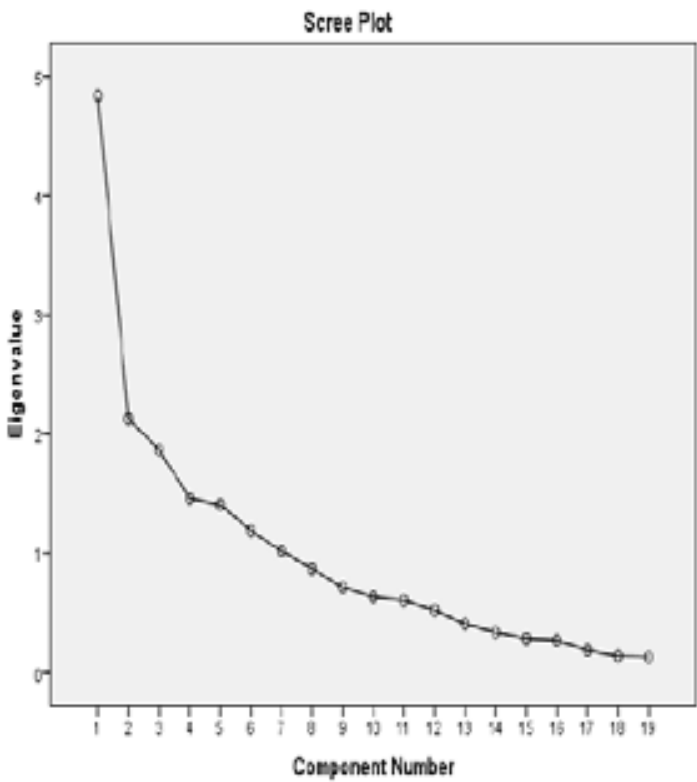

Figure 3. The Appropriateness of Number of Factor Components on Strategies for Effective WBL

The scree plot in Figure 3 revealed that, components four the plotted line turns sharply to the right which justified the four factors in Table 2.

\section{CONCLUSION}

The current state of technical and vocational education in Nigeria is worrisome due to notable challenges that bedeviled the system thereby undermining work-based learning of TVE for effectiveness. Workbased learning framework gives learners the opportunity to concurrently be exposed to instruction in both work and learning environments. Using principal component factor analysis, the study identified: policy, funding, attitudinal and linkage as challenging factors undermining effectiveness of work-based learning in Nigerian technical and vocational education. 
On the other hand, the study identified, training, administrative, institutional and facility or curriculum as strategic factors for effectiveness of workbased learning in Nigerian technical and vocational education. Based on the findings, the study recommended that (1) There should be very strong technical and vocational education linkage with industry for skills training of students through workbased learning framework and approach, (2) There should be continuous and periodic skill and competence-based training and retraining of technical and vocational education teachers and lecturers for effectiveness in service delivery, (3) The curriculum of technical and vocational education in Nigerian should be reviewed and reformed to ensure more attention to practical skills acquisition than theory, (4) There should be formulation of appropriate policies by the government for enhancing the image and attention giving to technical and vocational education in Nigeria, (5) There should be increase in budging allocation, funding and provision of necessary machines, and equipment for effective technical and vocational education in Nigeria, and (6) Formulating policies to guide the conduct of institution-industry linkage, activities of industry supervisors, contents of industry-based learning and activities of the trainees throughout the training session.

\section{REFERENCES}

[1] UNESCO, "Vocational \& Technical Education for a Strong \& Dynamic Society Revised Recommendation Concerning Technical \& Vocational Education," Korea, 2015.

[2] O. K. Awo, "Re-Engineering Vocational and Technical Education for Creativity, Innovation and Youth
Empowerment in Nigeria," Int. J. Agric. Home Econ. Educ., vol. 3, no. 1, pp. 69-80, 2016.

[3] O. J. Unongo, "Comparative Effects of Dialogic and Coaching Instructional Strategies on Students Performance, Interest And Retention in Motor Vehicle Mechanic Works in Technical Colleges in Benue State, Nigeria," University of Nigeria, 2015.

[4] B. Manyindo, "Pilot Project on CoOperation between Educational Institution and Enterprise in Technical Vocation Education in Ganda," in UNESCO Seminar, 2005.

[5] J. Nwosu and E. . Micah, "Technical and Vocational Education and Training as a Tool for National Sustainable Development in Nigeria," Int. J. Soc. Sci. Humanit. Invent., vol. 4, no. 9, pp. 3983-3988, 2017.

[6] Nigerian Educational Research and Development Council (NERDC), National Policy on Education. Federal Republic of Nigeria, 2014.

[7] V. E. Dike, "Addressing Youth Unemployment and Poverty in Nigeria: A call for action, not rhetoric," J. Sustain. Dev. Africa, vol. 11, no. 3, pp. 129-151, 2009.

[8] R. Okoye and A. M.O., "Technical and Vocational Education in Nigeria: Issues, Challenges and a Way Forward," J. Educ. Pract., vol. 7, no. 3, pp. 113-118, 2016.

[9] R. N. Oranu, "Vocational and Technical Education in Nigeria," 2004.

[10] S. O. Oryem-Origa, "Vocational Education and Manpower Development," Lagos, 2005.

[11] U. E. Okon, "Work-Based Learning Initiatives," in Step-B/World Bankassisted TVET Teachers Upskilling workshop, 2011.

[12] U. P. Amadi, "Appraising WorkBased Learning Experiences of Technical and Vocational (Teacher) 
Education and Training (TVTET) Programmes in Nigeria," Mediterr. $J$. Soc. Sci., vol. 4, no. 5, p. 137, 2013.

[13] R. Jerrard and M. Jefsioutine, "Reflections on Using Online Contracts for Work-Based Learning And Teaching in Art and Design," Art, Des. Commun. High. Educ., vol. 5, no. 1, pp. 55-69, 2006.

[14] Y. B. Kamin, A. A. Latib, N. F. Amin, M. S. Saud, and A. Ahmad, "Work-Based Learning: Employer Perspective towards the Automotive Industry," $A d v$. Sci. Lett., vol. 24, no. 4, pp. 2518-2521, 2018.

[15] L. C. Schrenko, "Standards and Guidelines for Work-Based Learning Programmes in Georgia," 2010.

[16] N. S. Amadi and S. T. Lazarus, "Current Issues in Agricultural Education in Tertiary Institutions in Nigeria," Int. J. Agric. Earth Sci., vol. 3, no. 1, pp. 13-18, 2017.

[17] B. Ashley, S. Amber, and F. Anthony, "Education by Nation: Multivariate Analysis," 2018.

[18] C. A. Kessler, "Divisive Key-Factors Influencing Farm Households Soil and Water Conservation Investment," J. Appl. Geogr., vol. 26, pp. 40-60, 2006.

[19] T. A. Amusa and J. B. Simonyan, 'Discrete Choice Model of Farmers' Willingness to Engage in Agroforestry-Based Farming in Southwest, Nigeria," Earth Atmos. Sci. Am. Assoc. Sci. Technol., vol. 1, no. 2, pp. 46-54, 2018.
[20] G. U. Ikenga, S. O. Afolabi, and P. Oru, "Technical and Vocational Education: Challenges and Prospects in the present day Nigeria," Warri, 2009.

[21] M. Abassah, "Analysis of the Problems and Prospect of the Technical College Teachers in Nigeria," in Proceedings of the 2011 International Conference on Teaching, Learning and Change, International Association for Teaching and Learning (IATEL), 2011, pp. $697-703$.

[22] G. M. Alam, K. E. Hoque, and K. O. Oloruntegbe, "Quest for a Better Operation System in Education: Privatization, Teacher Educationalization or Voucherilization: glimpsing from consumer and product perspectives," African J. Bus. Manag., vol. 4, no. 6, pp. $1202-1214,2010$.

[23] M. E. K. Amu and C. Offei-Ansah, "Linking Tertiary Institutions To Industries: Evidence from the Vocational and Technical Education Department of the University of Cape Coast," Int. J. Vocat. Tech. Educ., vol. 2, no. 5, pp. 53-60, 2011.

[24] D. P. Ojimba, "Vocational and Technical Education in Nigeria: Issues, Problems and Prospects, Dimensions (IPP)," J. Educ. Soc. Res., vol. 2, no. 9, pp. 23-30, 2012. 